PRAISE FOR THE ADVENTURES OF A CELLO

"Like Rostropovich, Carlos Prieto is a true champion of the cello. A creative artist, scholar, and storyteller, Carlos has been a prolific contributor to the flow of music throughout the Western Hemisphere, premiering compositions of some of the greatest contemporary composers and helping to nurture and develop an entire generation of Latin America's most talented musicians. I am privileged to know him as a colleague and honored to call him my friend."

- YO-YO MA

"From the time I was very young I've had a natural interest in music, but it was not revealed to me as a life's driving passion until the miraculous night when I discovered the soul of the cello in Carlos Prieto's hands. It was a revelation that left me infected forever after with the mysteries of music and the joy of a great friend."

- GABRIEL GARCÍA MÁRQUEZ

"Music as a great adventure of mind and body: this is what Carlos Prieto gives us in this spirited book."

\title{
- CARLOS FUENTES
}

"None of the great musicians or composers, past or present, has ever thought of telling the story behind the instrument that has so loyally accompanied them for so many years. What is the reason for this

deliberate, inexcusable oversight? I will not attempt to elaborate on this subject. This chronicle, by Carlos Prieto, a world-famous cellist and a cultured, sensitive man with the inexhaustible curiosity of the sages, has succeeded in solving this mystery so completely that I am finally at peace."

-FROM THE FOREWORD BY ÁlVARO MUTIS 
University of Texas Press 


\section{CARLOS PRIETO \\ The Adventures of a Cello \\ Revised Edition, with a New Epilogue}

TRANSLATED BY ELENA C. MURRAY

FOREWORD BY ÁLVARO MUTIS

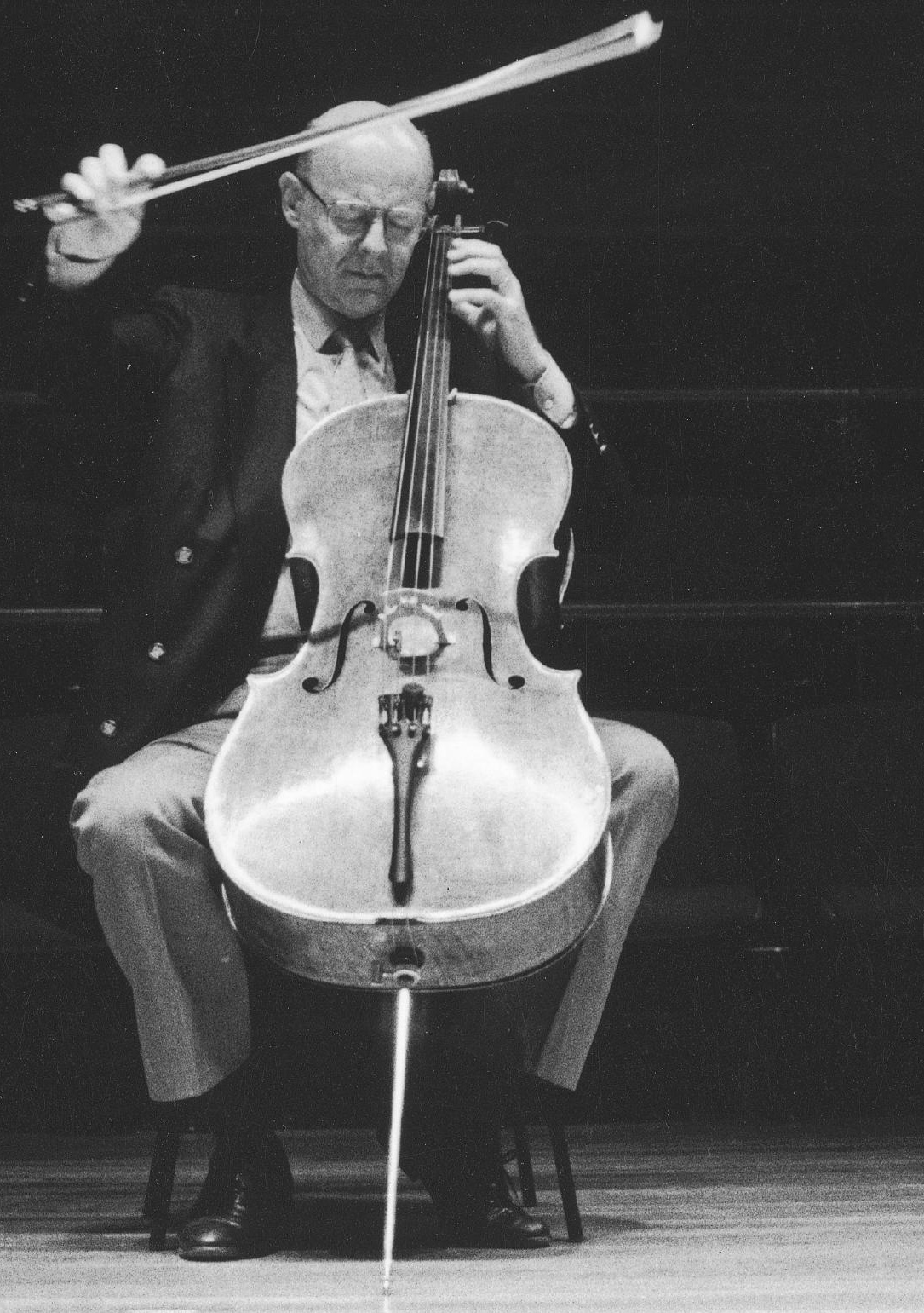


PUBLICATION OF THIS BOOK WAS MADE POSSIBLE THROUGH

THE GENEROUS SUPPORT OF THE FOLLOWING DONORS:

\author{
Jeanne and Michael Klein \\ in honor of Bob Freeman \\ Ellen Randall \\ in honor of Elle Alexander Middleton \\ and Lowell Lebermann.
}

Originally published in 1998 as Las aventuras de un violonchelo.

Copyright (C) 1998, Consejo Nacional para la Cultura y las Artes and

Fondo de Cultura Económica, México.

Translation copyright (C) 2006, 2012 by the University of Texas Press

All rights reserved

Printed in the United States of America

First University of Texas Press edition, 2006

University of Texas Press Revised Edition, 20II

First paperback reprint, 2018

Requests for permission to reproduce material from this work should be sent to:

Permissions, University of Texas Press,

P.O. Box 7819, Austin, TX 78713-7819

utpress.utexas.edu/rp-form

@ The paper used in this book meets the minimum requirements of ANsI/NISO Z39.48-I992 (RI997) (Permanence of Paper).

THE LIBRARY OF CONGRESS CATALOGED THE FIRST EDITION AS FOLLOWS:

Prieto, Carlos, 1937-

[Aventuras de un violonchelo. English]

The adventures of a cello / Carlos Prieto ; translated by Elena C. Murray ; foreword by Álvaro Mutis.

p. $\quad \mathrm{cm}$.

Includes bibliographical references (p. ), discography (p. ), and index. ISBN for the Revised Edition: 978-0-292-72393-I (cloth : alk. paper)

I. Violoncello. 2. Prieto, Carlos, I937- I. Murray, Elena C. II. Title.

ML9IO.P75I3 2006

$787.4-\mathrm{dc2} 2$

2006001346 
To María Isabel

To the memory of my parents, Cécile and Carlos

To my brother, Juan Luis

To Carlos Miguel, Isabel, and Mauricio

To the Prieto Quartets 
THIS PAGE INTENTIONALLY LEFT BLANK 